\title{
$\mathrm{Al}$ 単結晶表面上へのジンケート処理と 無電解 Ni-Pめっき
}

\author{
中田 毅*, 和田一郎 ${ }^{* *}$, 今井八郎 ${ }^{*}$, 池島賢司 ${ }^{* * *}$, \\ 井上晃一郎 ${ }^{* *}$, 渡辺 徹 ${ }^{* * *}$
}

\section{Zincate Treatment and Electroless Ni-P Plating on Al Single-Crystal Surface}

\author{
Takeshi NAKATA*, Ichıro WADA**, Hachıro IMAI*, Kenji IKESHIMA***, \\ Kouichiro INOUE ${ }^{* *}$ and Tohru WATANABE ${ }^{* * *}$
}

\begin{abstract}
Zincate treatment and electroless $\mathrm{N}_{1}-\mathrm{P}$ plating were conducted on the $\{100\},\{110\}$ and $\{111\}$ surfaces of $\mathrm{Al}$ single crystal produced using the Bridgman method. The deposition morphology of $\mathrm{Zn}$ particles and Ni-P film were studied through SEM observation and different crystallographic orientation. Once deposition of Zn reached a certain level, it increased only negligibly there after. $\mathrm{Zn}$ particles deposited after the second zincate treatment were refined and made homogeneous by dissolution in immersion in $\mathrm{HNO}_{3}$ solution after the first zincate treatment. It was recognized that convex objects were observed on the surface after $\mathrm{Zn}$ particle dissolution, and also deposited on the top of convex objects by the second zincate treatment. The differences in convex objects were recognized on the crystal surface of the $\mathrm{Al}$ single crystal. Observation of the plating layer surface morphology showed the $\{111\}$ surface to have the most homogeneous, smoothest surface.
\end{abstract}

Key Words Single Crystal, Zincate Treatment, Electroless N1-P Platıng, Crystallographic Orıentation, Hard Disc

\section{1. 緒言}

現在，磁気ハードディスクの基板材料には多結晶 $\mathrm{Al}$ 合金圧延板が使用されている。しかし圧延板は圧延集合 組織を持つため材料異方性を有しており，圧延方向によっ て機械的性質が異なる ${ }^{1)}{ }^{2}$ 。ここのような圧延板上にめっ きを施すと，めっきの応力によって压延方向または直角 方向に歪みが発生する可能性がある。さらに結晶粒界に 関したノジュール 3) (異常小突起) や, 個々の結晶方位 の違いによるめっき膜の不均一性などの問題も磁気八一 ドディスクの性能向上には考慮せねばならない点であ る ${ }^{4)}$ 。従来めっき膜の応力やノジュール，めっきの均一 性の問題に対しては主にめっき浴の改良やめっき条件の 工夫などによって対処してきた。本研究ではこれらの問 題に対して基板材料に注目して検討を行った。即ち本研

*芝浦工業大学 工学部（テ108 東京都港区芝浦 3-9-14）

Fac. of Eng., Shibaura Inst. of Tech (3-9-14, Shibaura, Minato-ku, Tokyo 108)

** 芝浦工業大学 大学院（テ108 東京都港区芝浦 3-9-14） Graduate School, Shibaura Inst of Tech. (3-9-14, Shibaura, Minato-ku, Tokyo 108)

***芝浦工業大学 大学院 [現 メルテックス(㮫（テ330 埼玉 県大宮市吉野町 2-1) ]

Graduate School, Shibaura Inst of Tech [Present Address Meltex Inc (2-1, Yoshıno-cho, Ohmiyashı, Saitama 330) ]

**** 東京都立大学 工学部 (一192-03 東京都八王子市南大沢1-1) Fac. of Eng, Tokyo Metropolitan Unıv (1-1 Minamiosawa, Hachıol1-shı, Tokyo 192-03)
究では粒界のない，また結晶異方性について考えやすい 単結晶 $\mathrm{Al}$ 板を用いることにより，それらの問題につい て検討を行った。

本研究では $\mathrm{Al}$ 単結晶を自作し, その単結晶から $\{100\}$, $\{110\},\{111\}$ 面の各結晶面を得, それらの面にジンケー 卜処理ならびに無電解 N1-Pめっきを施し，Zn および $\mathrm{N}_{1}-\mathrm{P}$ めっき膜の析出状況の観察を行い, 結晶面の違い に起因するそれらの成長過程の特徴を検討したものであ る。

\section{2. 実験方法}

図 1 に本研究で行った実験のプロセスを示す。

Aは電解研磨を行った試料に $15 ， 30 ， 45$ 秒の各時間 第一ジンケート処理を行った。

$\mathrm{B}$ は電解研磨後, 30 秒間第一ジンケート処理を行っ た試料に，続いて第二ジンケート処理を 30 秒間行った。

$\mathrm{C}$ は電解研磨後, 30 秒間第一ジンケート処理を行っ た試料を一旦硝酸で溶解し，その後第二ジンケート処理 を30秒間行った。

$\mathrm{D}$ はCのプロセスの後に $2,10,30,60$ 分間無電解 N1-Pめっきを行った。

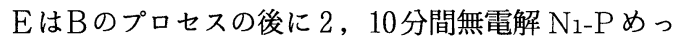
きを行った。

以上の工程を行った後,すべての試料に対し SEM 観察 を行った。次にそれぞれの処理方法について示す。 


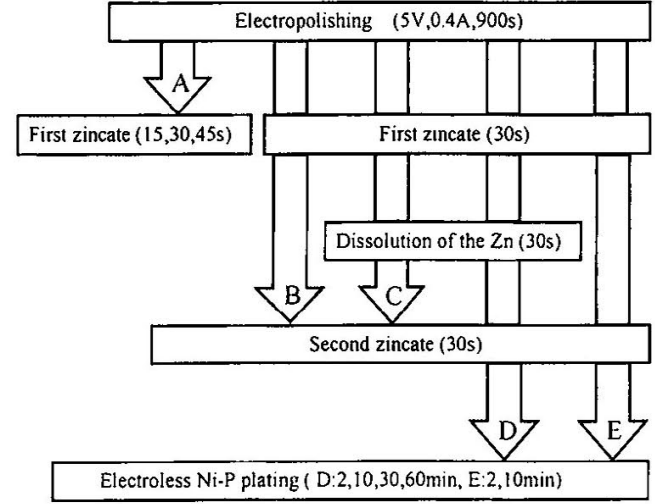

Fig. 1 Procedure of zincate and electroless plating for the specimens.

\section{1 素地単結晶の作製}

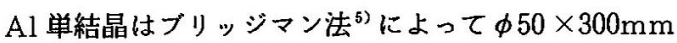
のロッド状のものを作製した。これを背面反射ラウエ法 により $\{100\},\{110\},\{111\}$ 面の 3 種類の面を方位調 整し，精密切断機によって切り出して基板材料とした。 切り出した基板は楕円形で，これをさらに6 等分して扇 形の試料とした。この試料はエメリー紙およびバフで研 磨後, Jacket 液で電解研磨を行い, 酸化皮膜や加工変 質層を除去する ${ }^{\circ}$ ととあに平滑な鏡面状の表面とした。

\section{2 ジンケート处理}

ジンケート処理はジンヶート液として市販の浴（上村 工業濑製 AD-3-1F 3X) を用い，500mLビーカー中で 行った。実験はまず，電解研磨を行った各面の試料に第 一ジンケート処理を $15,30,45$ 秒間の各時間行い, 処理 時間の変化に伴う $\mathrm{Zn}$ の析出状態について検討した。次 に第二ジンヶート処理についてす実験を行ったが，一般 には第一ジンケート処理後，第二ジンケート処理の前に 硝酸 $\left(50 \% \mathrm{HNO}_{3}\right)$ で一旦 $\mathrm{Zn}$ を溶解する処理 (30 秒) を行う。本実験ではその硝酸処理の効果についても検討 した。その際の第一ジンケート処理は 30 秒間である。 これら得られた試料は SEMによって Zn 粒子の析出状 態を観察した。これらいずれの実験も結晶面の違いおよ び処理条件の違いについて比較検討を行った。

\section{3 無電解 Ni-Pめっき}

各種ジンケート処理を行った試料について無電解 NiPめっきを行い，その表面形態を SEM観察によって検 討した。浴温は363Kである。無電解 Ni-P めっきは硝 酸溶解をしていない試料は 2,10 分間, 确酸溶解をし た試料については $2 ， 10 ， 30 ， 60$ 分間行った。無電解 Ni-Pぬっき液は基本的には塩化ニッケルに次亜りん酸 を用いた浴》) で市販の液 (上村工業(侏製 ニムデンHDX) である。ぬっき中は浴中に $\mathrm{N}_{2}$ ガスを吹き込むことによ
$\{100\}$
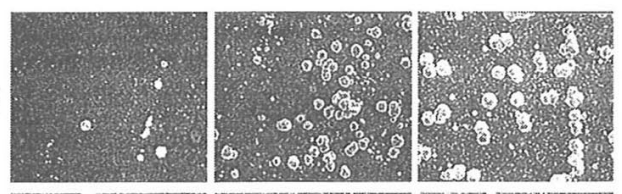

$\{110\}$
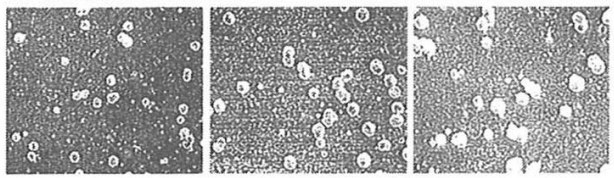

$\{111\}$

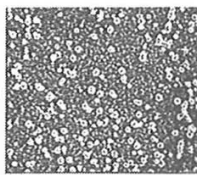

$15 \mathrm{~s}$

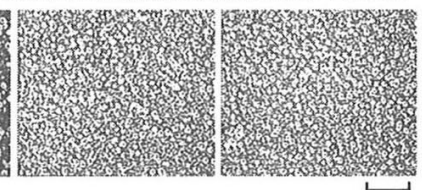

$30 \mathrm{~s}$

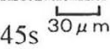

Fig. 2 SEM images of $\{100\},\{110\}$ and $\{111\}$ surfaces treated with the first zincate process for 15,30 and $45 \mathrm{~s}$.

り，液中の酸素を排出するとともにかく找を行った。

\section{3．実験結果および考察}

\section{1 ジンケート処理}

$\mathrm{Al}$ 単結晶の $\{100\},\{110\},\{111\}$ 面の各試料に15, 30，45秒間第一ジンケート処理を行った表面の SEM 写 真を図 2 に示す。白く粒状に見える部分が $\mathrm{Zn}$ 粒子で， 黒く見える部分が $\mathrm{Al}$ 素地である ${ }^{8)}$ 。3 種類の結晶面で それぞれZn粒子の析出状態が異なる。\{100\} 面では異 なった大きさの粒子が析出し，他の 2 面に比べて析出が 疎である。また $\{110\}$ 面では $10 \mu \mathrm{m}$ 程度の大きさの粒 子と，それよりあ小さな粒子が密に $\mathrm{Al}$ 素地を覆ってい る。\{111\} 面では $5 \mu \mathrm{m}$ 以下の粒子が密に析出している のが見られる。

ジンケート処理の時間で比較した場合，これら３面に 共通していることは，15秒間と 30 秒間のジンケート姏 理では処理時間とともに Zn 粒子の析出量が多くなるが, 30 秒間と 45 秒間では析出量にほとんじ差は見られない。 このことからジンケート处理を 30 秒以上行っても Zn 粒 子の析出はある一定量加ら增加せず，本実験で用いたジ ンケート浴では処理時間は 30 秒で十分であるといえる。 次に第二ジンケート処理を行うが，一般には第一ジン ケート処理によって析出した Zn粒子を硝酸により溶解 した後に第二ジンケート処理が行われる。しかしここで はその硝酸溶解を行わずに続いて第二ジンケート処理を 施す実験む行った。その結果を図 3 に示す。図に示すよ うに第二ジンケート処理後の Zn粒子の析出状況は第一 ジンケート処理後の状況之変わって扔らず，疎らな状態 になっている。また第一ジンケート処理で析出した大き な Zn粒子を覆うようにさらに成長している。さらに， 


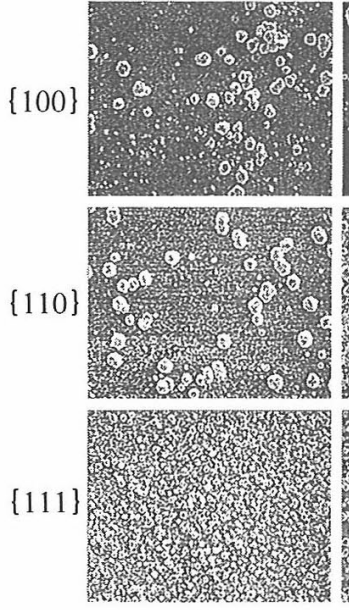

(a)
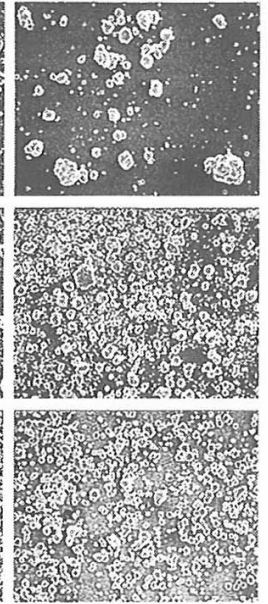

(b) $\longdiv { 3 0 \mu m }$
Fig. 3 SEM images of $\{100\},\{110\}$ and $\{111\}$ surfaces treated with the first zincate process (a), and after the second zincate process without the dissolution process using $\mathrm{HNO}_{3}$ solution (b).

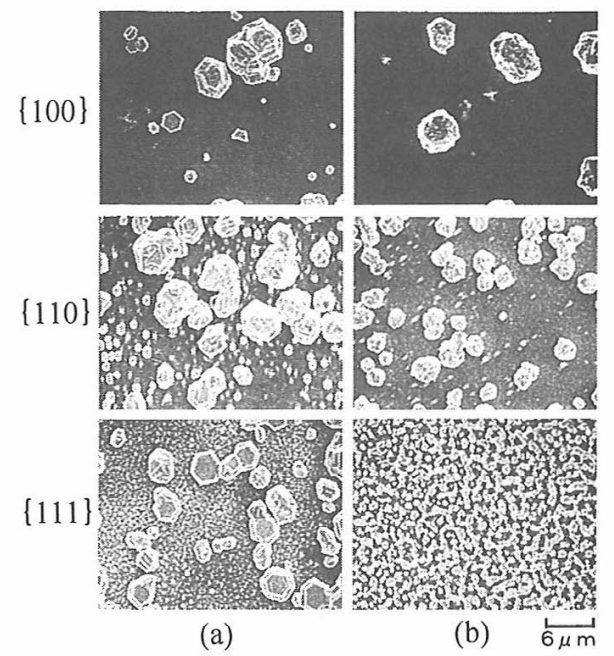

Fig. 4 SEM images of $\{100\},\{110\}$ and $\{111\}$ surfaces treated with the second zincate process without dissolution process using $\mathrm{HNO}_{3}$ solution (a) and with the dissolution process (b), after the first zincate process.

素地上にも新たに微細な Zn粒子が析出していることす 確認された。

図 4 (a) に各結晶面に第一ジンケート処理を行った後 に硝酸で Zn を溶解せず，直ちに第二ジンケート処理を した表面の SEM写真を，また図４（b）には第一ジンケー 卜処理後に硝酸で Znを溶解し, 次に第二ジンヶート処 理を行った表面を示す。図 4 (a)において $\{100\}$ 面およ

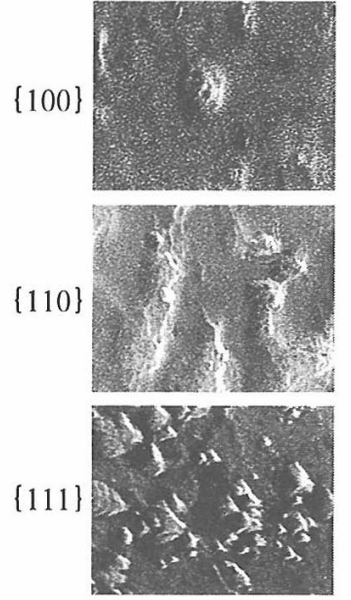

(a) $\longdiv { 1 \mu \mathrm { m } }$
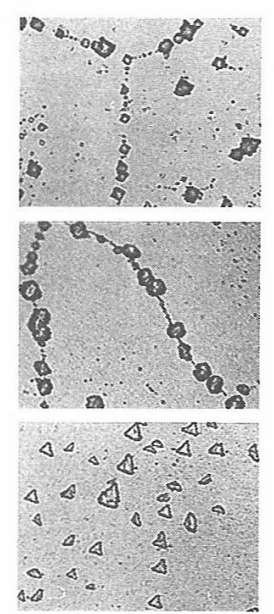

(b) $\underset{20 \mu \mathrm{m}}{\breve{m}}$
Fig. 5 SEM images of $\{100\},\{110\}$ and $\{111\}$ surfaces after the dissolution process (a), and photographs of pit appeared $\mathrm{Al}$ surface after etching by $\mathrm{HF}$ solution (b).

び $\{110\}$ 面では粒子サイズが不均一であったものが， 図4 (b)では均一化が促されている。また $\{111\}$ 面では 一度硝酸で Znを溶解した後に第二ジンヶート处理を行っ たものの方が，Znの析出粒子は微細で均一になってい る。このことから第一ジンケート処理後の硝酸による Zn 粒子の溶解は，第二ジンケート処理で析出する Zn 粒 子を均一にする効果があるといえる。

次に図 5 (a) に第一ジンケート処理後に硝酸で Zn 粒 子を溶解した $\mathrm{Al}$ 単結晶の表面を示す。この写真加ら $\mathrm{Al}$ 素地上にかなりの凹凸が確認できる。この凹凸の形 状は 3 面各々で特徴的で, $\{100\}$ 面は正四角錐, $\{110\}$ 面は複雑ではあるが四角錐，\{111\} 面は正二角錐である。 この凸部の形は图 5 (b) に示した $\mathrm{Al}$ のエッチング時に 形成されるエッチピット（凹形）と同じであり， $\mathrm{Al} の$ 溶解によって結晶学的に表面エネルギーの低い $\{111\}$ 面が表面に現れたもの之考えられる。一般に原子密度の 大きい結晶面ほど溶解に対して不活性である 面心立方構造であることから\{111\} 面が原子密度が最 大であり，あっとあ不活性である。ジンケート処理の上 うな置換反応の際に生ずる溶解においても同様であると 考えられる。つまり原子密度に起因する溶解に対する活 性の違いが，結晶面による析出形態の違いを生じさせる 一因になっていることが考えられる。そして溶け出した $\mathrm{A} 1$ の当量に相当する分だけ $\mathrm{Zn}$ 原子が置換析出し， $\mathrm{Zn}$ の結晶粒子を形成させる。その $\mathrm{Zn}$ 粒子はこれらの凸 上に析出していたあのと考えられる

\{100\} 面では，この凸部の数が他の結晶面に比して少 ない。このことから $\{100\}$ 面上では一つの凸上に Zn 
粒子が多量に析出した結果, 一つが $10 \mu \mathrm{m}$ 程度の粒子が 疎に形成されていたと考えられる。これに対し，\{111\} 面では凸部が比較的多く, 密に存在している。その結果 として Zn粒子は密で均一な析出形態をとったと考えら れる。また $\{110\}$ 面ではこれら二つの面の中位的な析 出密度となっている。つまりジンヶート处理において $\mathrm{Al}$ の溶解状態か，析出する $\mathrm{Zn}$ 粒子の密度や均一性を 決めると考えられる。

\section{2 無電解 Ni-Pめっき}

図 6 (a) に第一ジンケート処理後，硝酸溶解をせずに 第二ジンケート処理を続けて行った試料に 2 分間無電解 Ni-Pめっきを施した表面を示し，図 6 (b)には10分間 無電解 Ni-Pめっきを施した表面を示す。

めっき膜の表面は 3 種類の面でそれぞれ異なった形態 を示している。特に10分間めっき後(b)ではいずれる， ジュール状の Ni-P が見られる ${ }^{3)}$ 。 $\{100\}$ 面では $1.5 \mu \mathrm{m}$ 程度のノシュールが疎らに析出しており，その周囲に微 細なノジュールも析出している。粗大なノジュールは, 数個のノジュールが集合し $3 \mu \mathrm{m}$ 程度に成長している。 また，\{110\} 面ではさらにノジュールの形状が柾らであ る。またそれらの大きなノジュールは粗大に析出してお り，めっき膜は均一ではない。しかし $\{111\}$ 面は他の 2 面に比べて微細である。以上のように Ni-Pめっき膜 の表面状態は図 3 の第二ジンケート処理後の $\mathrm{Zn}$ 粒子の 分布状況之同様の傾向になっている。次に図 7 に第一ジ ンケート処理後， $\mathrm{Zn}$ 粒子を硝酸で溶解し，第二ジンケー 卜処理を行った試料に無電解 Ni-Pめっきを施した表面 を示す。

$\{100\}$

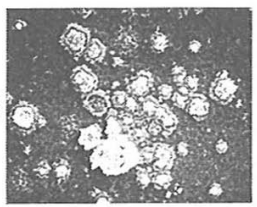

$\{110\}$
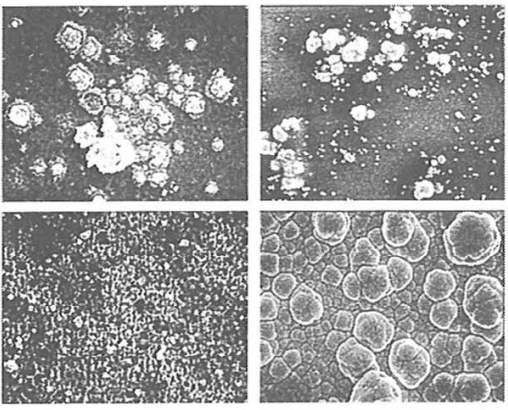

$\{111\}$

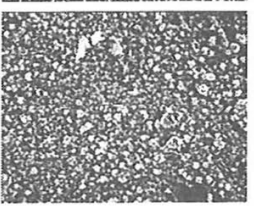

(a) 2 min

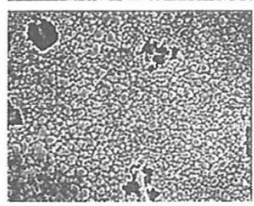

(b) $10 \mathrm{~min} \quad \overleftarrow{6 \mu \mathrm{m}}$
Fig. 6 SEM images of $\{100\},\{110\}$ and $\{111\}$ surfaces after the electroless Ni-P plating for $2 \mathrm{~min}$. (a) and $10 \mathrm{~min}$. (b) after the second zincate process without the dissolution process.

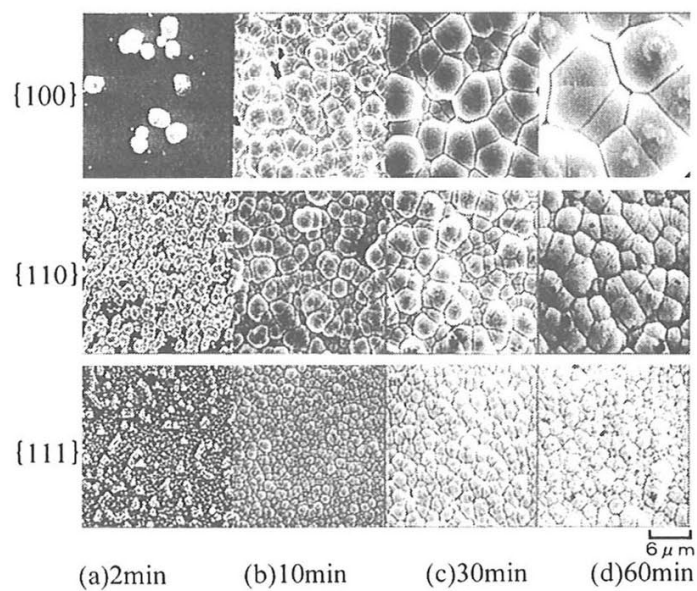

Fig. 7 SEM images of $\{100\},\{110\}$ and $\{111\}$ surfaces after the electroless $\mathrm{Ni}-\mathrm{P}$ plating for $2 \mathrm{~min}$. (a), 10 min. (b), $30 \mathrm{~min}$. (c) and $60 \mathrm{~min}$. (d) after the second zincate process with the dissolution process.

これらの写真を比較すると, 10 分間めっき以降では $\mathrm{Al}$ のそれぞれの結晶面でノシュールそのあのの形や分 布にそれほどの差異は見られない。しかし硝酸溶解を行っ ていない図6のあのに比べて図7の方が全体的に均一な 表面を形成している。特に $\{100\}$ 面でその傾向は大き い。これに対し $\{111\}$ 面ではノジュールは非常に繳密 で均一に形成されている。

さらにめっき時間を 30 分, 60 分と長くすると, めっ き時間の経過とともにノジュールが大きく成長していく 過程が見られる。特に $\{100\}$ 面にそれが顕著に現れ， 10 分間めっきで $1.5 \mu \mathrm{m}$ 程度であったノジュールが 60 分 間めっきでは $10 \mu \mathrm{m}$ 程度にまで成長している。このよう な傾向は各面とも同様であるが, めっき膜そのあのはジ ンケート処理の時と同様, \{111\} 面で最む均一な表面が 得られた。

\section{3 ジンケート処理および無電解 Ni-Pめっき工程 の考察}

图 8 に第一ジンケート処理 (a)，続いて硝酸溶解を行 わないで第二ジンケート処理を行ったもの(b)，さらに 無電解 Ni-Pめっき (c) の各工程の同一場所での SEM 観 察写真を示す。図中の矢印が同一場所を示している。但 しこれらに関しては SEM 観察の際, 各工程直後に試料 が高真空環境下に置かれるため，上述した一連の工程よ りも表面活性度に変化が生じていることが考えられる。 ここではあえてそれらを考慮せず析出形態の変化を観察 した。まず第一ジンケート炕理によって $\mathrm{Zn}$ 粒子が析出 し，第二ジンケート処理によって第一ジンヶート処理で 析出した Zn粒子が少し粗大化し，そして無電解 Ni-P めっきで，析出した Zn粒子が溶解しその残った凸部か 
らそれを覆うように Ni-Pめっき膜が成長していく様子 がわかる。

この図 8 の写真および前述した図4，図7などから，

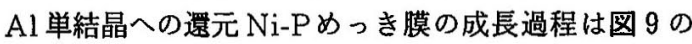
模式図に示すように進行していくと考えられる。Al 単 結晶試料の表面を電解研磨で鏡面とし(1), 第一ジンケー 卜処理で $\mathrm{Al}$ が溶解し，それに变わって溶解した $\mathrm{Al} の$ 当量分だけ Zn原子が置換析出する(2)。Znは溶け残っ た $\mathrm{Al}$ 素地上に析出し，処理時間とともに成長する(3)。 しかし図 2 で示したように，およそ30秒以上ジンケー 卜処理を行っても $\mathrm{Zn}$ の析出量および大きさに変化が見 られない。これは第二ジンケート処理によって置換析出 するZn原子は先の Zn粒子に重なるように析出し大き くなるが，ある程度大きく成長した粒子は脱落している 可能性がある。しかし第二ジンケート処理の前に第一ジ

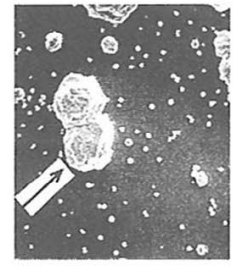

(a)

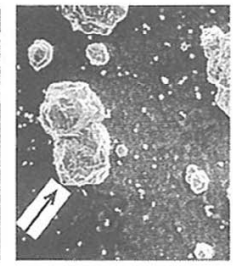

(b)

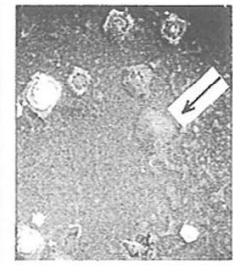

(c) $\longdiv { 6 \mu \mathrm { m } }$
Fig. 8 SEM images of the same site in surface treated by each processes.

(a) After the first zincate process for $30 \mathrm{~s}$.

(b) After the second zincate process for $30 \mathrm{~s}$.

(c) After the electroless Ni-P plating for $2 \mathrm{~min}$.
ンヶート処理で析出した Zn 粒子を硝酸溶解すると (4'), Al 表面には多少の凹凸が形成されるが, 活性状態の均 一な表面が現れ，そのために第二ジンケート処理を行っ た時に(5'), Al 素地上にあらためて均一で微細な $\mathrm{Zn}$ 粒子が析出すると考えられる。これは $\mathrm{Al}$ 表面は第一ジ ンケート姏理の前は活性な部分と不活性な部分が不均一 な状態であったものが，第一ジンケート炕理とその硝酸 溶解によって均一状態となるためと考える。そのため第 二ジンケート姏理によってあらためて析出する Zn 粒子 の大きさおよび分布とあ均一になると考えられる。

そして Zn粒子が均一に析出した $\mathrm{Al}$ 基板を無電解 $\mathrm{Ni}$ Pめっき浴に入れると, Zn 粒子が溶解し，その部分 (厳密にはその極めて近傍) に Ni が置換析出し, 続い て Ni-Pめっきが Ni を触媒としながら還元析出してめっ き膜が形成される $\left(6^{\prime}\right)^{100.11 \% 。 の よ う な こ と か ら ~} \mathrm{Ni}-\mathrm{P}$ めっき膜の状態はジンケート処理の $\mathrm{Zn}$ 粒子の分布状態 に依存する。

\section{4. 結 䜒}

Al 単結晶を作製し， $\{100\} ，\{110\}$ および $\{111\}$ 面 の 3 種類の特徴的な結晶面にジンケート処理ならびに無 電解 Ni-Pめっきを行い，それらの析出状態について検 討した。その結果, 以下のことが分かった。

(1) 第一ジンゲート処理後の硝酸溶解工程は第二ジンケー 卜処理で析出する Zn 粒子を微細で均一にする効果があ る。

（2）無電解 Ni-Pめっきの均一性は, ジンケート処理に より得られる Zn 粒子の析出の均一性に影響される。

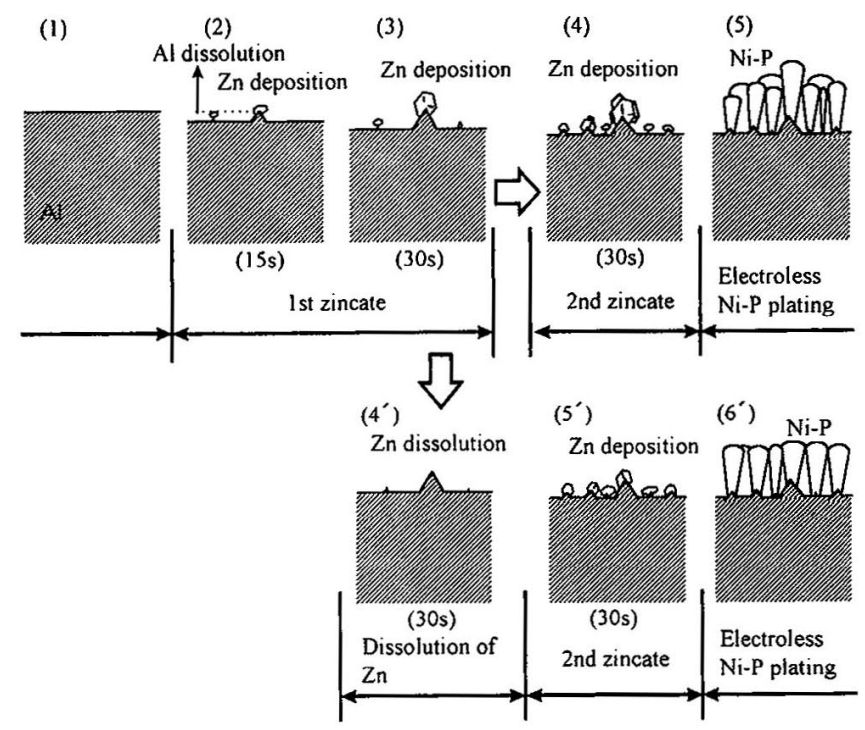

Fig. 9 Schematic diagram of variation on the surfaces morphology. 
（3）ジンケート処理および無電解 Ni-Pめっき工程で得 られるめっき膜の表面形態は結晶面によって異なり， \{111\} 面で最も均質で平滑なめっき表面が得られた。 (4) ジンケート処理並びに無電解 Ni-Pめっきにおいて, 純 $\mathrm{Al}$ 単結晶の結晶異方性が確認できた。またこれら異 方性は結晶学的な表面エネルギー, 即ちそれらの起因と 思われる原子密度が大きな影響を与えていることが考え られる。

本研究を遂行するにあたり, 多大なご援助を賜りまし た三菱アルミニウム株に深謝いたします。

(Received February 27, 1997 ; Accepted May 19, 1997)

文 献
1）飯島万寿男；磁気テープ・ディスク \&光ディスクの新展開

文 献
1) 飯島万寿男; 磁気テープ・ディスク \&光ディスクの新展開
之需給動向, p. 121（綜合包装出版(侏), 1987）

2）渡包 徹, 中田 毅 ; 表面技術, 45，1100（1994）

3 ）田代雄彦, 千葉国雄, 福田 豊, 中尾英弘, 渡辺 徹; 表 面技術，47，349（1996）

4 ）渡辺 徹 ; 金属表面技術, 37，440（1986）

5 ）堂山昌男; 単結晶, p. 3 (内田老鶴圃, 1990)

6）加瀬敬年 ; 最新めっき技術, p. 28（産業図書(株，1983）

7 ）神戸徳蔵；無電解めっき, p. 13（橫書店, 1984）

8 ) 田代雄彦, 千葉国雄, 福田 豊, 中尾英弘, 本間英夫 ; 表 面技術，45，720（1994）

9) 大谷南海男 ; 金属表面工学, p. 8 (日刊工業新聞, 1969)

10）渡辺 徹; 表面技術，41，346（1990）

11）田村忠義 ; 金属秋季臨時増刊号, p.18（アグネ，1978） 